Рекомендована д. фармац. наук, проф. Б. П. Громовиком

УДК 615.1:658.7

\title{
КЛАСИФІКАЦІЯ ТА АНАЛІЗ ВИТРАТ НА УПРАВЛІННЯ ЗАПАСАМИ У ФАРМАЦЕВТИЧНИХ КОМПАНІЯХ
}

\author{
๑ю. Є. Новицька, О. В. Посилкіна, Р. В. Сагайдак-Нікітюк
}

Національний фармацевтичний університет, Харків

\begin{abstract}
Резюме: визначено сутність витрат на управління запасами. Проаналізовано витрати на управління запасами фармацевтичних компаній. Досліджено динаміку витрат на управління запасами для умов фармацевтичного виробництва. Обґрунтовано класифікацію витрат на управління запасами у фармацевтичних компаніях.

Ключові слова: витрати, управління запасами, фармацевтичні компанії, лікарські засоби.
\end{abstract}

Вступ. Створення ефективної системи управління сучасною фармацевтичною компанією (ФК) зі складною логістичною інфраструктурою неможливе без аналізу структури та механізму управління логістичними витратами, головний елемент яких утворюють витрати на управління запасами. Традиційно витрати на утримання запасів складають приблизно 37-40 \% усіх логістичних витрат $[1,5]$. Але оскільки в оптових компаніях та у дистриб'юторів запаси мають значно більшу питому вагу в активах, то і їх витрати на утримання запасів мають більшу частку в загальних логістичних витратах порівняно 3 виробничими компаніями і становлять понад $50 \%[7,15]$.

Розуміння сутності і величини логістичних витрат необхідні для розрахунку цін на лікарські засоби (ЛЗ), реалізації концепції інтеграційного логістичного менеджменту, управління та конт- ролю за ефективністю логістичного фармацевтичного ланцюга і т.п.

Як показав аналіз літературних джерел, логістичні витрати в США сьогодні складають 7 $16 \%$ від сукупних доходів компаній або до $45 \%$ від загальних і адміністративних витрат. У структурі логістичних витрат транспортно-заготівельні витрати становлять до $60 \%$, витрати на утримання запасів - до 35 \% (табл. 1) [4-6].

Отже, актуальність вивчення та удосконалення процесу управління логістичними витратами викликана тим, що частка логістичних витрат в структурі вартості товарів досить значна (табл. 2) і актуальним $є$ пошук резервів оптимізації цих витрат [1, 4, 7].

Проведені дослідження свідчать, що значну частку логістичних витрат складають витрати на транспортування, складування та утриманням запасів, що пов'язано з необхідністю створен-

Таблиця 1. Структура логістичних витрат на підприємствах США

\begin{tabular}{|c|c|c|}
\hline \multirow{2}{*}{ Складові витрат } & \multicolumn{2}{|c|}{ Витрати } \\
\hline & млрд дол. США & $\%$ \\
\hline $\begin{array}{l}\text { 1. Витрати на зберігання запасів, } \\
\text { у тому числі: } \\
\text { • } \quad \text { сплата відсотків } \\
\text { • податки і амортизація } \\
\text { - } \quad \text { складські витрати }\end{array}$ & $\begin{array}{c}277 \\
53 \\
161 \\
63\end{array}$ & $\begin{array}{c}38,21 \\
7,31 \\
22,21 \\
8,69\end{array}$ \\
\hline $\begin{array}{l}\text { 2. Транспортні витрати, } \\
\text { у тому числі: } \\
\text { • } \quad \text { автомобільного транспорту } \\
\text { • } \quad \text { залізничного транспорту } \\
\text { • } \quad \text { водного транспорту } \\
\text { • } \quad \text { трубопровідного транспорту } \\
\text { - } \quad \text { повітряного транспорту } \\
\end{array}$ & $\begin{array}{c}415 \\
333 \\
33 \\
22 \\
10 \\
17\end{array}$ & $\begin{array}{c}57,24 \\
45,93 \\
4,55 \\
3,03 \\
1,4 \\
2,34 \\
\end{array}$ \\
\hline 3. Витрати, пов'язані з експедуванням товарів & 5 & 0,69 \\
\hline 4. Витрати на управління дистрибуцією & 28 & 3,86 \\
\hline Сукупні логістичні витрати & 725 & 100 \\
\hline
\end{tabular}

ISSN 2312-0967. Фармацевтичний часопис. 2015. № 1 
Економіка аптечних і фармацевтичних підприємств Economics of phapmaceutical structures

Таблиця 2. Структура логістичних витрат у виручці від реалізації фармацевтичних компаній, \%

\begin{tabular}{|l|c|c|c|c|c|}
\hline \multirow{2}{*}{\multicolumn{1}{|c|}{ Складові логістичних витрат }} & \multicolumn{5}{|c|}{ Країна } \\
\cline { 2 - 6 } & Франція & Німеччина & Голландія & Великобританія & США \\
\hline Витрати на транспортування & 2,43 & 5,81 & 1,44 & 2,65 & 2,92 \\
\hline Витрати на складування & 2,50 & 2,60 & 2,07 & 2,02 & 1,83 \\
\hline $\begin{array}{l}\text { Витрати, пов'язані з прийомом та } \\
\text { оформленням замовлень }\end{array}$ & 1,30 & 2,27 & 1,38 & 0,72 & 0,55 \\
\hline Витрати на адміністрування & 0,65 & 0,65 & 0,32 & 0,27 & 0,39 \\
\hline Витрати на утримання запасів & 1,83 & 0,72 & 1,53 & 2,08 & 1,91 \\
\hline Всього & 8,71 & 12,05 & 6,74 & 7,74 & 7,60 \\
\hline
\end{tabular}

ня належних умов транспортування і зберігання фармацевтичної продукції та підтримки обгрунтованого рівня запасів. Але спроби гармонізувати різні цілі в більшості випадків призводять до зростання витрат в процесі руху фармацевтичної продукції, що негативно впливає на її ціну $[8,9]$. Це зумовлено відсутністю теоретичних і методичних досліджень в сфері управління логістичними витратами в фармації, що потребує створення науково-організованого механізму управління цими витратами.

Актуальність розрахунку та обліку витрат на управління запасами в оптових ФК і зумовила необхідність формування принципів і методичних підходів до управління цими витратами.

Методи досліджень. Результати дослідження ґрунтувалися на використанні методів експертної оцінки, прийомів сходження від загального до конкретного, контент-аналізу.
Результати й обговорення. Витрати на управління запасами в оптових ФК - це сукупність витрат на управління рухом фармацевтичної продукції по всьому логістичному ланцюгу - від виробника ЛЗ до кінцевого споживача. Вони охоплюють витрати на:

- закупівлю фармацевтичної продукції;

- поповнення запасів;

- утриманням запасів;

- виконання замовлень.

Для дослідження структури і динаміки витрат на управління запасами в оптовій ланці фармацевтичної галузі як об'єктів дослідження були обрані такі компанії, як ТОВ «БаДМ», ТОВ «Фітолек», КП «ЛО «Луганська фармація», ТОВ «ІКВЕЛ», ТОВ «Медсервіс».

Динаміку структури витрат на досліджуваних вітчизняних ФК наведено на рисунку 1 .

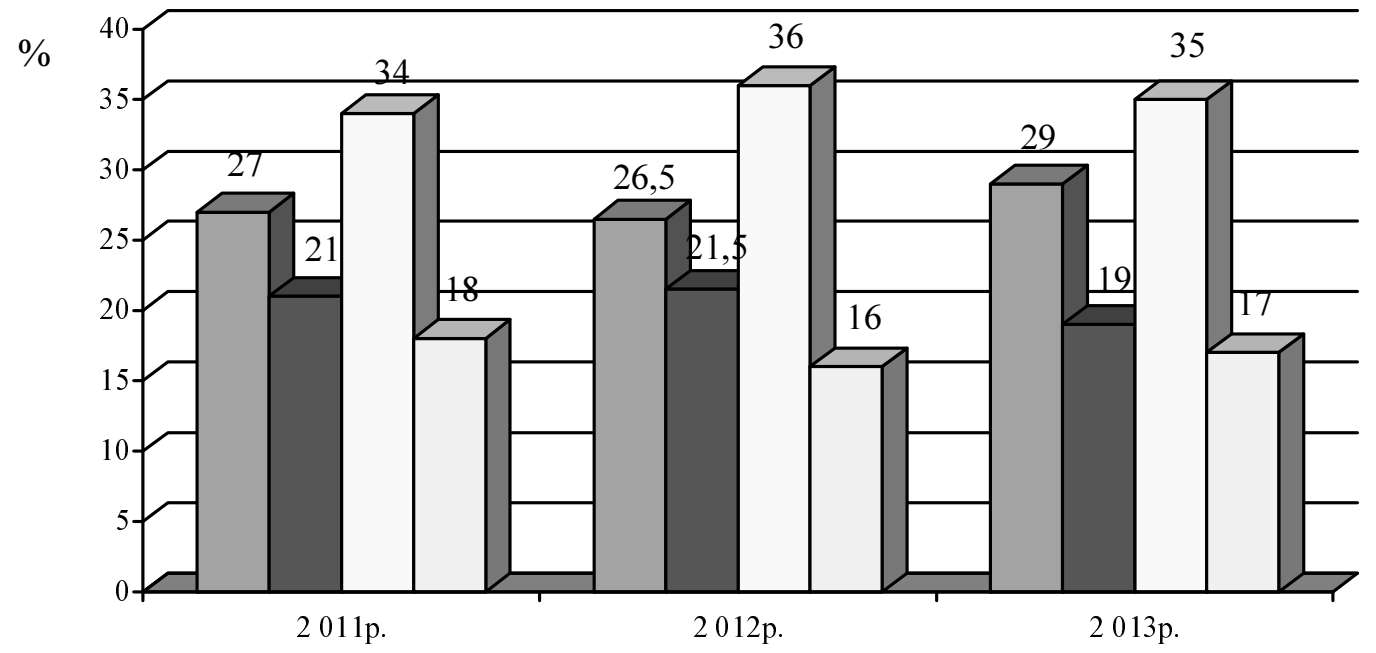

$\square$ витрати на закупівлю фармацевтичної продукції;

$\square$ витрати на поповнення запасів;

$\square$ витрати на утриманням запасів;

$\square$ витрати на виконання замовлень

Рис. 1. Динаміка структури витрат на управління запасами в досліджуваних оптових ФК.

ISSN 2312-0967. Pharmaceutical review. 2015. № 1 
Економіка аптечних і фармацевтичних підприємств Economics of phapmaceutical structures

Як видно з даних рисунка, протягом досліджуваного періоду спостерігаються незначні коливання структури витрат на управління запасами, що пов'язано з посиленням вимог належних практик до процесів зберігання та транспортування фармацевтичної продукції, змінами попиту на ЛЗ, підвищенням конкуренції на фармацевтичному ринку тощо.

Витрати на закупівлю складають основну частину витрат, пов'язаних з запасами, та явля- ють собою сукупність витрат на виконання логістичних операцій на стадії закупівлі:

$\checkmark \quad$ витрати на аналіз ринку;

$\checkmark$ витрати на вибір постачальників;

$\checkmark \quad$ витрати на розробку плану закупівлі (рис. 2).

Запропонована класифікація витрат на закупівлю в оптових ФК наведена на рисунку 3.

Витрати на поповнення запасів відображають витрати матеріальних, фінансових, інформацій-

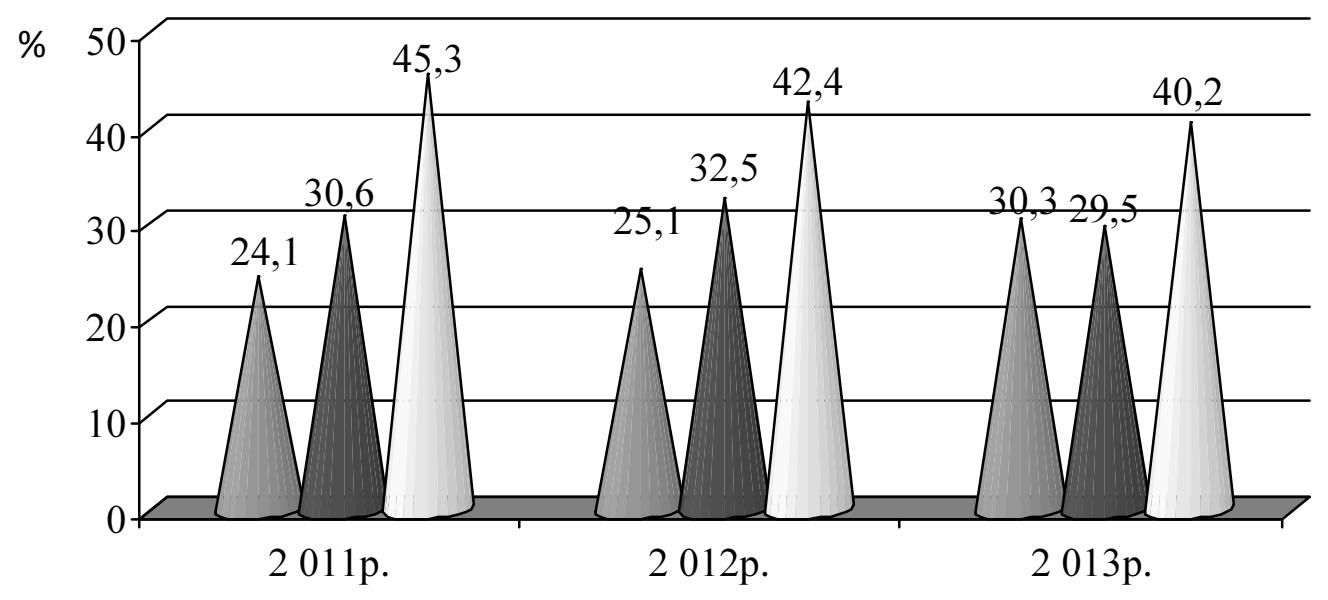

витрати на аналіз ринку;

витрати на вибір постачальників;

$\square$ витрати на розробку плану закупівлі

Рис. 2. Динаміка структури витрат на закупівлю фармацевтичної продукції в оптових ФК.

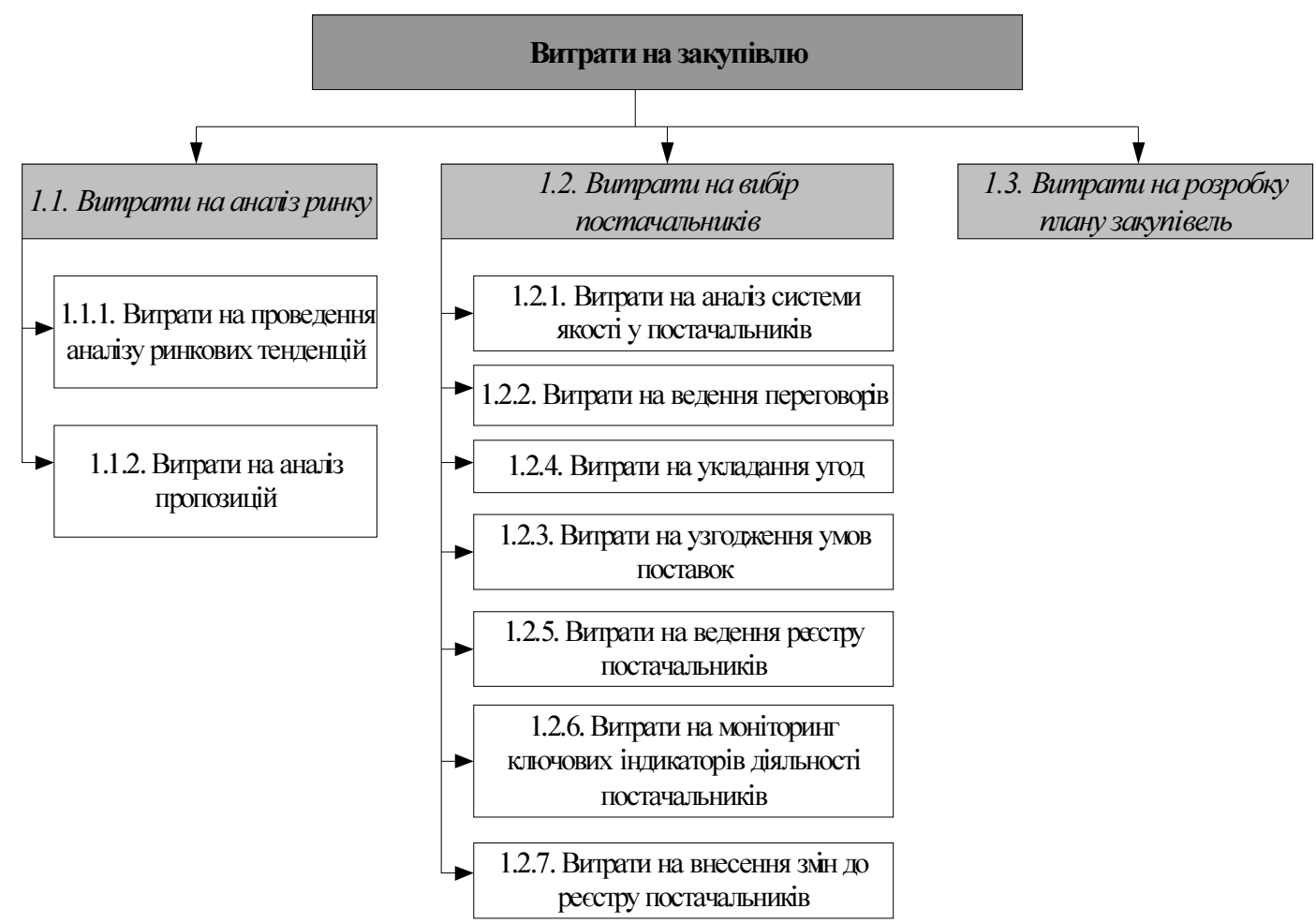

Рис. 3. Запропонована класифікація витрат на закупівлю в оптових ФК.

ISSN 2312-0967. Фармацевтичний часопис. 2015. № 1 
них, трудових та інших виді ресурсів, необхідних для оформлення та отримання замовлення. Вони включають витрати, що виникають при підготовці і розміщенні замовлень у постачальників, організації доставки фармацевтичної продукції в оптову ФК і т. п. Динаміка структури витрат на поповнення запасів в оптових ФК наведена на рисунку 4.

Як видно з наведених даних, суттєву частку цих витрат складають витрати на організацію доставки та відстеження процесу транспортування фармацевтичної продукції від постачальників. Таким чином, витрати на поповнення запасів пов'язані 3 діяльністю тих підрозділів оптових ФК, які беруть участь у прийнятті та реалізації рішень по цих операціях з метою забезпечення необхідної потреби в фармацевтичній продукції згідно з розробленим планом ії продажів.

Витрати на утримання запасів - це витрати матеріальних, фінансових, інформаційних, трудових та інших видів ресурсів, необхідних для забезпечення збереженості та підтримки належної якості фармацевтичної продукції, яка знаходиться в запасах на території оптових ФК або у процесі внутрішнього переміщення. Ці витрати пов'язані $з$ діяльністю транспортного та складського господарств оптових ФК, що виконують роботи безпосередньо з обслуговування фізичних запасів фармацевтичної продукції.

Відповідно, витрати на утримання запасів складаються 3 витрат на належне утримання складських приміщень; забезпечення належного руху запасів; обслуговування запасів та вартості втрат від ризиків (рис. 5).
Економіка аптечних і фармацевтичних підприємств Economics of phapmaceutical structures

Динаміку структури витрат на утримання запасів в оптових ФК наведено на рисунку 6.

Сьогодні витрати на утримання запасів практично не знаходять відображення в звітності ФК, але фінансові ресурси, іммобілізовані в запаси, відволікаються від інших напрямків діяльності компанії чи інших напрямків інвестування. Тому ці витрати суттєво впливають на фінансовий стан ФК і потребують ретельного обліку та аналізу.

Витрати на виконання замовлень споживачів являють собою витрати, пов'язані з виконанням логістичних операцій на стадії реалізації фармацевтичної продукції:

- витрати на пошук замовників (33,6 \%);

- витрати на прийом замовлень (32,5 \%);

- витрати на комплектацію замовлень і контроль $(34,9 \%)$ (рис. 7$)$.

Запропоновану для оптових ФК класифікацію витрат на виконання замовлень наведено на рисунку 8.

Запропонована класифікація витрат на управління запасами в оптових ФК спрямована на їх оптимізацію завдяки аналізу кожної складової і обґрунтування резервів їх економії. На підставі проведених досліджень виявлені такі напрямки оптимізації витрат: необхідність раціонального використання складських площ; підвищення продуктивності праці завдяки механізації та автоматизації складських операцій; підвищення кваліфікації складського персоналу; детальне вивчення ринкової ситуації, обсягу та структури попиту; впровадження процесних технологій; застосування адекватних моделей управління запасами; удосконалення системи обліку і документації запасів; застосування

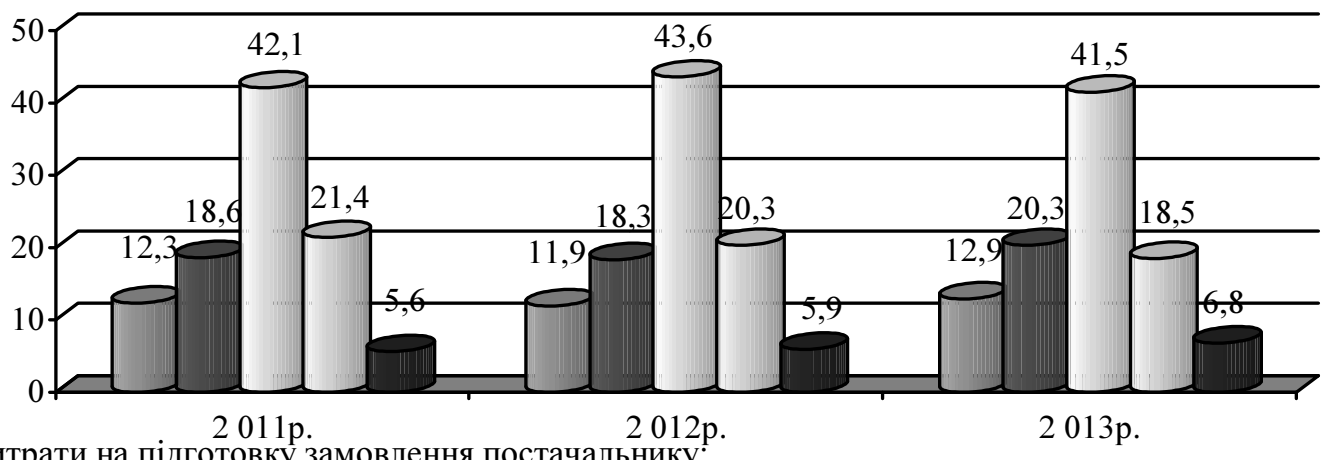

$\square$ витрати на підготовку замовлення постачальнику;

$\square$ витрати на розміщення замовлення;

$\square$ витрати на організацію доставки та відстеження процесу транспортування фармацевтичної продукції від постачальників;

$\square$ витрати на приймання замовлення від постачальників;

口 витрати, пов’язані з оформленням претензій до постачальника (при необхідності)

Рис. 4. Динаміка структури витрат на поповнення запасів в оптових ФК.

ISSN 2312-0967. Pharmaceutical review. 2015. № 1 


\section{3. Витрати на утримання запасів}

3.1. Витрати на належне утримання складських приміщень

3.1.1. Вартість амортизації складських прим і-

- щень, складського обладнання, вим ірювальних пристроїв

\subsection{2. Витрати на ремонт} складських прим іщень,

складського обладнання, вимірювальних пристроїв

3.1.3. Витрати на заробітну плату складського персоналу

\section{1.4. Нарахування на} заробітну плату складського персоналу

3.1.5. Витрати на комунальні платежі

3.1.6. Витрати на розвиток складської інфраструктури

\section{2. Витрати на забезпечення \\ належного руху запасів}

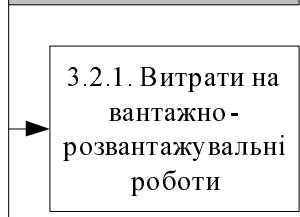

3.2.2. Витрати на приймальний контроль

3.2.3. Витрати на - транспортування в зонну зберігання

\subsection{4. Витрати на} транспортування iз зони зберігання в зону комплектації замовлення

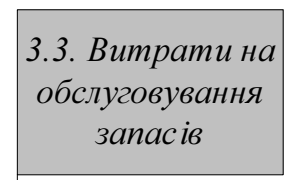

3.4. Bapmicmb втрат від ризиків

3.4.1. Втрати від псування запасів

на інформаційне забезпечення й документацію

\subsection{2. Витрати} на моніторинг запасів і умов їх зберігання

3.3.3. Витрати на регламентацію процесу управління запасами

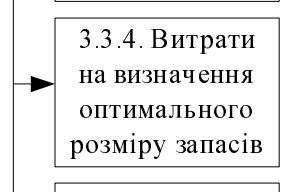
3.3.5. Витрати на страхування запасів
3.4.2. Втрати від крадіжок

3.4.3. Втрати від старіння запасів (закінчення терміну придатності) фармацевтичної продукції

\subsection{4. Втрати від} сплати штрафних санкцій за неналежне виконання або невиконань замовлення
3.5 .

Альтернативні витрати

3.5.1. Недоодержаний прибуток внаслідок іммобілізації оборотних коштів в запасах

3.5.2. Витрати, пов'язані $з$ потребою у додатковому капіталі внаслідок утворення надлишкових запасів

Рис. 5. Запропонована класифікація витрат на утримання запасів в оптових ФК.

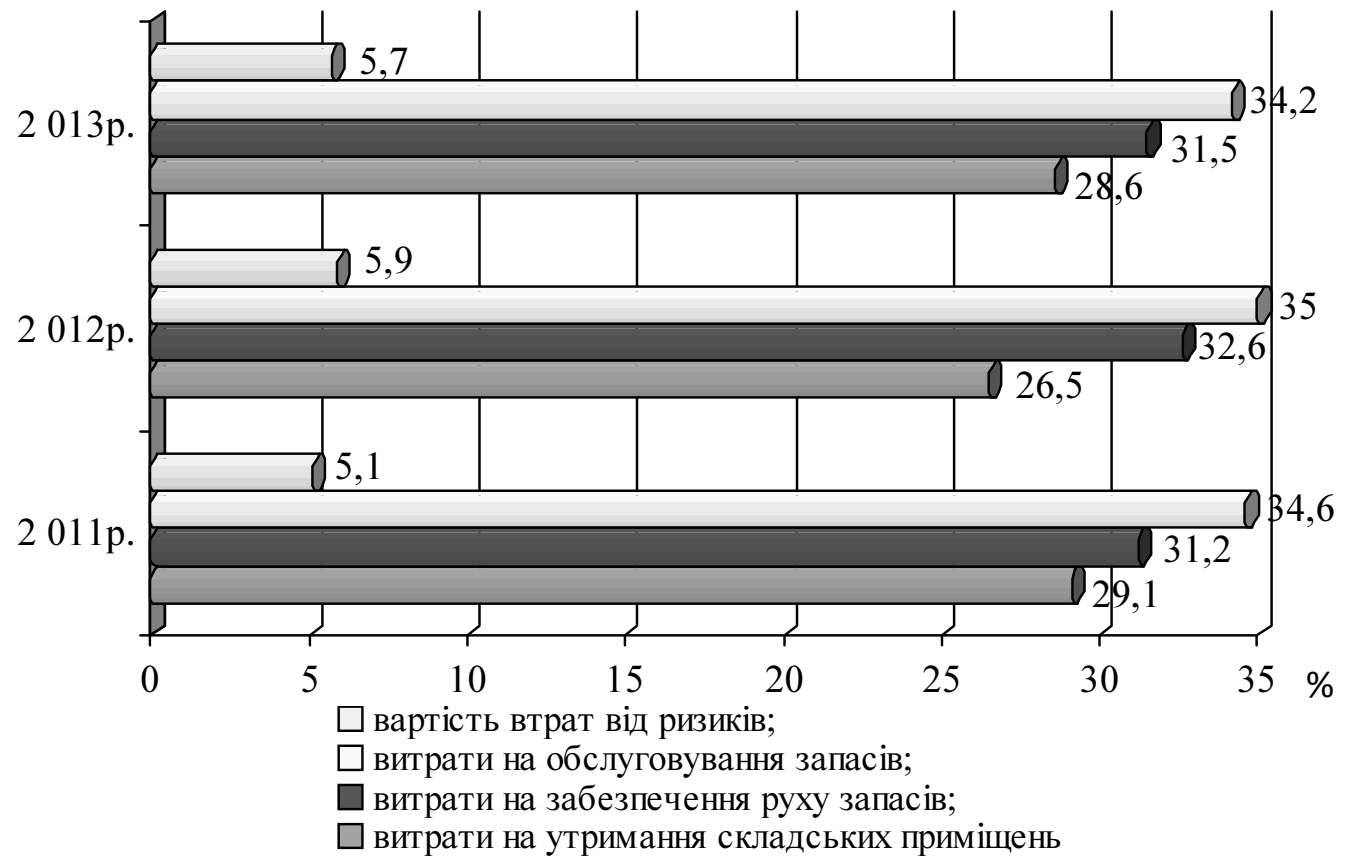

Рис. 6. Динаміка структури витрат на утримання запасів в оптових ФК.

ISSN 2312-0967. Фармацевтичний часопис. 2015. № 1 


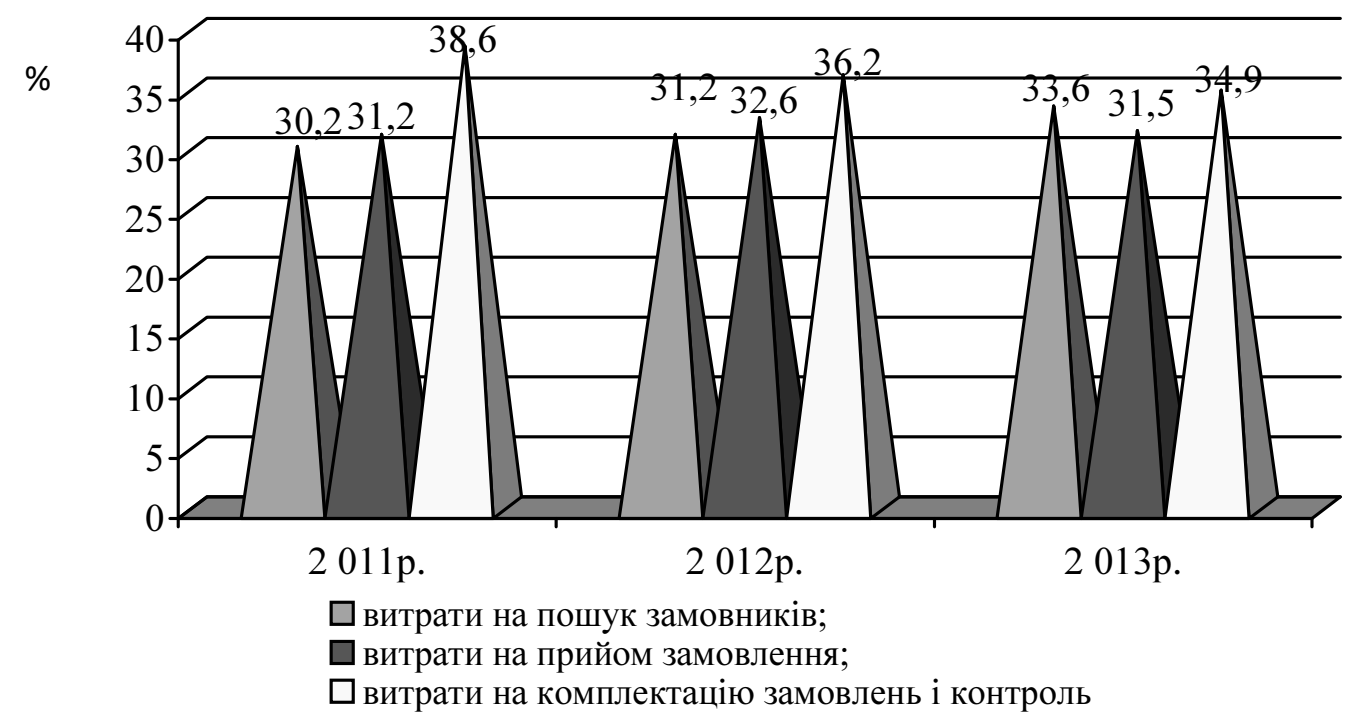

Рис. 7. Динаміка структури витрат на виконання замовлення.

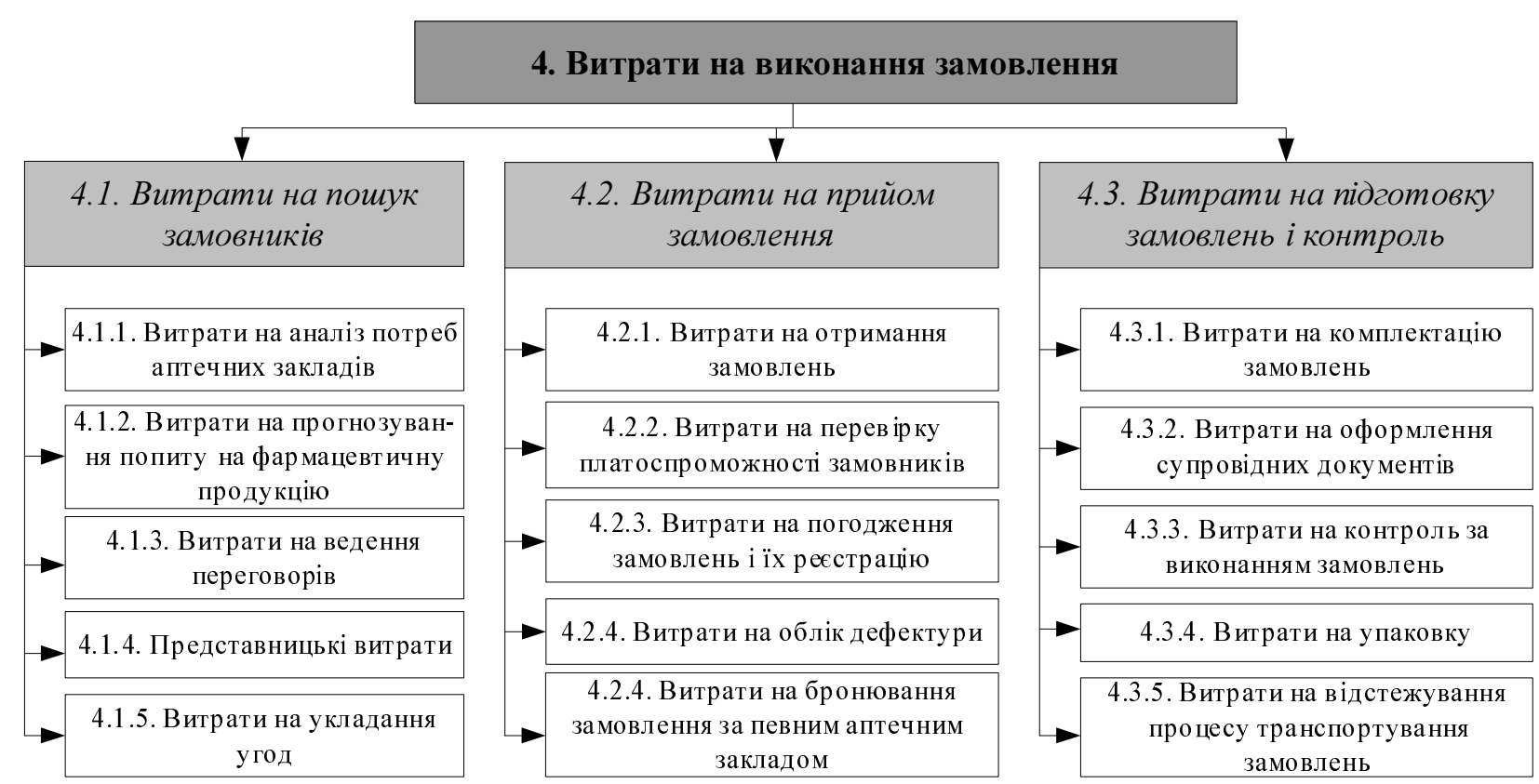

Рис. 8. Запропонована класифікація витрат на виконання замовлень в оптових ФК.

трекінг-систем в процесі перевезення фармацевтичної продукції, впровадження методів маршрутеризації транспортних засобів при доставці фармацевтичної продукції замовникам тощо.

Висновки. Досліджено актуальність проблеми управління запасами фармацевтичних компаній, що пов'язане з високою часткою цих витрат у загальній сумі логістичних витрат.

Запропоновано структуру витрат на управління запасами в оптових фармацевтичних ком- паній, яка включає витрати на закупівлю фармацевтичної продукції, поповнення і утримання запасів і виконання замовлень, розроблено класифікацію цих витрат і досліджено їх динаміку за 2011-2013 роки на прикладі ТОВ «БаДМ», ТОВ «Фіто-лек», КП «ЛО «Луганська фармація», ТОВ «ІКВЕЛ», ТОВ «Медсервіс».

Визначено напрямки оптимізації витрат на управління запасами в умовах оптової ланки фармацевтичної галузі.

ISSN 2312-0967. Pharmaceutical review. 2015. № 1 
Економіка аптечних і фармацевтичних підприємств

Economics of phapmaceutical structures

\section{Література}

1. Бауэрсокс Д. Логистика: интегрированная цепь поставок / Д. Бауэрсокс, Д. Клосс ; пер. с англ. - [2-е изд.]. - М. : ЗАО «Олимп-Бизнес», 2005. - 640 с.

2. Сергеев В. И. Корпоративная логистика. 300 ответов на вопросы профессионалов / В. И. Сергеев ; под общ. и науч. ред. проф. В. И. Сергеева. - М. : ИНФРА-М, 2006. - 976 с.

3. Логистика : учебник / Б. А. Аникин, В. В. Дыбская, А. А. Колобов ; под. ред. Б. А. Аникина ; [3-е изд.], перераб. и доп. - М. : ИНФРА-М, 2007. - 367 с.

4. Дыбская В. В. Логистика : учеб. / В. В. Дыбская, Е. И. Зайцев, В. И. Сергеев; под ред. В. И. Сергеева. М. : Эксмо, 2008. - 944 с.

5. Крикавський $€$. В. Економіка логістичних систем : моногр. / за наук. ред. Є. В. Крикавського. - Львів : Видво Нац. ун-ту «Львівська політехніка», 2008. - 596 с.

6. Крикавський $Є$. В. Логістичні системи : навч. посіб. / Є. В. Крикавський, Н. В. Чернописький. - Львів : Видво Нац. ун-ту «Львівська політехніка», 2009. - 264 с. 7. Логістичний менеджмент фармацевтичного підприємства: моногр. / О. В. Посилкіна, Р.В.Сагайдак-Нікітюк, Г. В. Загорій та ін. - Х. : НФаУ, 2011. - 772 с.

8. Положення (стандарт) бухгалтерського обліку 16 «Витрати» : Затверджено наказом МФУ 31.12.1999 р. № 318 (зі змінами та доповненнями).

9. Про бухгалтерський облік та фінансову звітність в Україні : Закон України від 16.07.1999 р. № 996 // Офіційний вісник України. - 1999. - № 33. - Ст. 71. (зі змінами та доповненнями).

10. Грошовий Т. А. Використання методів апріорного ран- жування факторів при проведенні маркетингових досліджень / Т. А. Грошовий, М. Б. Павлюк, О.В.Тригубчак // Економічна освіта та наука: досвід та перспективи : матеріали наук.-практ. конф. - Х., 2007. - С.179-180.

11. Гудзенко О. П. Оптимізація діяльності оптово-роздрібних фармацевтичних підприємств у сучасних умовах ринку / О. П. Гудзенко, С. В. Барнатович // Вісник фармації. - 2005. - № 2. - С. 43-46.

12. Денисова М. Н. Фармацевтические рынки в Едином экономическом пространстве / М. Н. Денисова, А. А. Ишмухаметов, В. А. Дмитриев. - М. : Изд-во ИИА «Ремедиум», 2009. - 76 с.

13. Євтушенко О. М. Оцінювання ефективності комунікативної діяльності фармацевтичної фірми за умов різновекторного впливу : метод. рек. / О. М. Євтушенко, 3. М. Мнушко. - Х., 2011. - 23 с.

14. Куценко С. А. Сегментація аптек-замовників оптовими фармацевтичними фірмами за бажаними критеріями обслуговування / С. А. Куценко, 3. М. Мнушко // Актуальні питання фармацевтичної та медичної науки та практики. - 2006. - Т. 2. - Вип. XV. - С. 359-365.

15. Мнушко 3. М. Розвиток логістичного моделювання діяльності фармацевтичних підприємств на вітчизняному ринку / З. М. Мнушко, С. А. Куценко, Л. П. Дорохова // Фармац. журн. - 2005. - № 5. - С. 3-7.

16. Посилкіна О. В. Формування сучасної системи управління логістичними витратами на фармацевтичних підприємствах / О. В. Посилкіна, Р. В. Сагайдак, О. О. Яремчук // Вісник фармації. - 2007. - № 1 (49). - С. 46-51.

\title{
КЛАССИФИКАЦИЯ И АНАЛИЗ ЗАТРАТ НА УПРАВЛЕНИЕ ЗАПАСАМИ В ФАРМАЦЕВТИЧЕСКОЙ КОМПАНИИ
}

\author{
Ю. Е. Новицкая, О. В. Посылкина, Р. В. Сагайдак-Никитюк \\ Национальный фармацевтический университет, Харьков
}

Резюме: определена сущность затрат на управление запасами. Проанализированы затраты на управление запасами фармацевтических компаний. Исследована динамика затрат на управление запасами для условий фармацевтического производства. Обоснованно классификацию затрат на управление запасами в фармацевтических компаниях.

Ключевые слова: затраты, управление запасами, фармацевтические компании, лекарственные средства.

\section{CLASSIFICATION AND ANALYSIS OF COST OF INEVENTORY MANAGEMENT STOCK IN PHARMACEUTICAL COMPANIES}

\author{
Yu. Ye. Novitskaya, O. V. Posilkina, R. V. Sahaidak-Nikitiuk \\ National University of Pharmacy, Kharkiv
}

\begin{abstract}
Summary: the essence of inventory management is defined. The cost of inventory management in pharmaceutical companies was analyzed. Dynamics of post of the inventory management for pharmaceutical companies conditions was investigated. Cost classification of inventory management in pharmaceutical companies was justified.
\end{abstract}

Key words: costs, inventory management, pharmaceutical companies, medications. 